\title{
Isolation and Transcriptional Regulation of the Fructose 1,6-Bisphosphate Aldolase Gene FBA1 in the Psychrophilic Yeast Cystofilobasidium capitatum
}

\author{
Fujimura Shuki*1, Uchino Masataka*2, Ito Takashi*1, \\ Mroda Takao*1, Nagaoka Toshinori*1, Miyaji Tatsuro*1, \\ Nakagawa Tomoyuki*1, Takano Katsumi*2 and Tomizuka Noboru*1 \\ * 1 Department of Food Science and Technology, Faculty of Bioindustry, Tokyo University of Agriculture \\ 196 Yasaka, Abashiri, Hokkaido 099-2493, Japan
}

* 2 Department of Applied Biology and Chemistry, Faculty of Applied Bioscience, Tokyo University of Agriculture Sakuragaoka 1-1-1, Setagaya-ku, Tokyo 156-8502, Japan

In this study, we report the primary structure of fructose 1,6-bisphosphate aldolase encoded by Cystofilobasidium capitatum FBAl (CcFBAl) and the regulation of its gene expression. CcFBAl consists of a $1,080 \mathrm{bp}$ ORF corresponding to a protein of 360 amino acid residues, and the calculated molecular weight of CcFbalp is 39,626 Da. The CcFbalp has both aldolase class-II signatures 1 and 2. CcFBAl is expressed at the same level during growth on several different carbon sources, although expression level may be slightly higher on glucose. Transcription of CcFBAl is not influenced by temperature or existence of oxygen, although it was reduced during the stationary phase. We show that CcFbalp is a constitutive enzyme in $C$. capitatum, and suggest that FBAl could be used as a marker for the detection of pectinolytic psychrophilic yeasts using the PCR method.

(Received Sep. 11, 2006 ; Accepted Dec. 6, 2006)

Psychrophiles are microorganism which exhibit optimal growth at $15^{\circ} \mathrm{C}$ or lower. As psychrophiles are able to grow at low temperatures they occasionally cause spoilage of foodstuffs during preservation. Therefore, contamination of foodstuffs by psychrophiles must be avoided, and rapid methods to detect psychrophiles in foodstuffs are required.

Putrefaction of foods is caused by metabolism of some microorganisms, thus much study regarding food spoilage generally estimates the cell number of microorganisms in foods. Nowadays, to detect and estimate the cell number of living microorganisms contaminating foods, expression of essential genes can be observed and cell numbers estimated by various methods including lumino-assay, measurement by $\mathrm{CO}_{2}$, DNA chip and quantitative PCR. Therefore, it is useful to identify new markers to detect psychrophiles in foodstuffs by the PCR method.

Psychrophilic cells synthesize a set of proteins which may provide a protective mechanism and alter metabolism in order to adapt in cold environments. In Saccharomyces cerevisiae, the mesophilic yeast, low temperature responsive ( $L O T$ ) genes have been extensively studied which are induced in response to cold to provide not only stress responses but also developmental and physiological changes ${ }^{1)}$. In $S$. cerevisiae, FBAI encoding fructose 1,6-bisphosphate aldolase (FBA: EC 4.1.2.13) has been reported to be one of the LOT genes induced by cold stress ${ }^{11}$. FBA is a glycolytic enzyme that catalyzes reversible aldol cleavage or condensation of fructose 1,6 -bisphosphate into dihydroxyacetone-phosphate and glyceraldehyde 3 phosphate. The enzyme fulfills an amphibolic function as it is involved in both catabolic (glycolysis) as well as anabolic pathways (gluconeogenesis and Calvin cycle). Therefore, we considered FBA to be a potential target to analyze the cold response of psychrophiles and to detect psychrophiles in the

\footnotetext{
* 1 E-mail : Fujimura Shuki ; 50040007@cp.bioindustry.nodai.ac.jp, ITo Takashi ; 50040001@cp.bioindustry.nodai.ac.jp, MYoDA Takao; tlmyouda@bioindustry.nodai.ac.jp, MiYAJI Tatsuro ; t-miyaji@bioindustry.nodai.ac.jp, NAKAGAWA Tomoyuki ; t-nakaga@bioindustry.nodai.ac.jp, TomizukA Noboru;n-tomizu@bioindustry.nodai.ac.jp

* 2 E-mail : UCHINO Masataka ; muchino@nodai.ac.jp, TAKANO Katsumi ; takano@nodai.ac.jp
} 
foodstuffs.

We selected the basidiomycetous yeast Cystofilobasidium capitatum, which is able to utilize pectin as a sole carbon source ${ }^{2), 3)}$, as a model for psychrophiles contaminating foodstuffs. Here, we report(i) cloning of the gene encoding the FBA from C. capitatum, and (ii) how FBA synthesis is regulated by various growth conditions, e.g., carbon sources, oxygen, growth phase and temperatures.

\section{Materials and Methods}

\section{Strains, media and cultivation}

C. capitatum strain PPY- 1 was used as the wildtype strain. Complex Yeast-Peptone-Dextrose (YPD) and synthetic MI media ${ }^{4)}$ were used for the cultivation of strain PPY-1. The carbon source in the MI medium was one of the following; $1 \%(\mathrm{w} /$ v) galacturonic acid, $1 \%(\mathrm{v} / \mathrm{v})$ glycerol, $1 \%(\mathrm{w} /$ v) glucose or $1 \%(\mathrm{w} / \mathrm{v})$ pectin $(\mathrm{DE} 10 \%$ or 90\%) (Sigma Chemicals, St. Louis, MO). The initial $\mathrm{pH}$ of the media was adjusted to 5.0. Cultivation $(100 \mathrm{~m} \ell)$ was performed anaerobically or aerobically at $5{ }^{\circ} \mathrm{C}, 10^{\circ} \mathrm{C}, 15^{\circ} \mathrm{C}$, or $20^{\circ} \mathrm{C}$ with rotary shaking at $150 \mathrm{rpm}$ in $500 \mathrm{-m} \ell$ Erlenmeyer flasks, and growth was followed by measuring the optical density at $660 \mathrm{~nm}$.

Escherichia coli $\mathrm{DH} 5 \alpha$, which was used for plasmid propagation, was grown at $37^{\circ} \mathrm{C}$ in $2 \mathrm{xYT}$ medium, when necessary being supplemented with ampicillin $(50 \mu \mathrm{g} / \mathrm{m} \ell)$.

\section{Cloning and sequencing of the CCFBA1 gene}

Total RNA was extracted from the cells grown on pectin by the acid-guanidinium thiocyanate-phenol -chloroform method using ISOGEN (Nippon Gene Co., Ltd., Toyama, Japan), and reverse transcribed according to the instructions of the 3'-Full RACE core set (Takara Shuzo Co., Ltd., Kyoto, Japan).

The cDNA encoding the FBA was cloned by chance when we were cloning the cDNA encoding polygalacturonase from $C$. capitatum by 3'race PCR using F-1 primer ; 5'-gTNgCNgCNgCNAARAARTgY AC-3', and Oligo dT adaptor primer (Takara Shuzo Co., Ltd.). The amplified ca 1.3 -kbp fragment was cloned into the pT7blue T-vector (Novagen Inc., Madison, WI, USA). The DNA fragment was sequenced by the dideoxy cycle sequencing method with a PRISM DyeDeoxy Terminator Cycle Sequencing kit and a DNA sequencer model 3130 (Applied BioSystems, Foster, CA, USA). The nucleotide sequence of $C c F B A 1$ has been submitted to DDBJ / EMBL / GenBank databases under the accession no. AB 244669.

The CLUSTAL $\mathrm{X}$ version 1.8 program was used for multiple alignment of sequences, construction of neighbor-joining phylogenetic tree ${ }^{5)}$, and 1,000 times bootstrap analysis for evaluation of phylogenetic tree topolog $y^{6)}$.

\section{Northern analysis}

Total RNA was extracted from the cells by the acid-guanidinium thiocyanate-phenol-chloroform method using ISOGEN (Nippon Gene Co., Ltd.). Briefly, $20 \mu \mathrm{g}$ of an RNA sample was electrophoresed on a $1.0 \%$ agarose gel containing $20 \mathrm{mM}$ MOPS buffer, $1 \mathrm{mM}$ EDTA, and 2.2 M formaldehyde.

After electrophoresis, capillary transfer to a nylon membrane ( Hybond- + ; Amersham Pharmacia Biotech UK Ltd., Buckinghamshire, UK) in $20 \mathrm{x}$ SSC ( $1 \mathrm{x} \mathrm{SSC}$ is $0.15 \mathrm{M} \mathrm{NaCl}$ plus $0.015 \mathrm{M}$ sodium citrate) was performed. The DNA probe including of the entire coding region of $C c F B A 1$ was labeled with an AlkPhos DIRECT kit (Amersham Pharmacia Biotech UK Ltd.).

\section{Results and Discussion}

\section{Primary structure of $C$. capitatum FBA1}

We cloned the complete $C$. capitatum FBA1 cDNA gene. The CcFBAI consists of a 1,080 bp ORF corresponding to a protein of 360 amino acid residues and has 180 bases in the 5'-untranslated region, as shown in Fig. 1. The calculated molecular weight of CcFbalp is ca. 39, $626 \mathrm{Da}$, and its deduced amino acid sequence shows high similarity to those of the Fbalp from Filobasidiella neoformans var. neoformans JEC21 (72\% identity), the Ustilago maydis Fbalp (66\% identity), and the Neurospora crassa Fbalp (64\% identity). The CcFbalp contains the aldolase class-II signature 1 , which is located in the first half of the sequence and contains two histidine residues that have been shown to be involved in binding a zinc ion ${ }^{7}$. Furthermore, CcFba $1 p$ contains the aldolase class-II signature 2, which is located in the C-terminal section and contains clustered acidic and glycine residues (Fig. 1). Until now, two distinct classes of FBAs occur in nature, which differ in their enzymatic mechanisms ${ }^{8)}$. ClassII aldolases are mainly found in prokaryotes and fungi, and they are homodimeric enzymes which require a divalent metal ion, generally zinc, for their activity. These facts show that CcFbalp, gene product of $C c F B A 1$, is a class II aldolase, and is able 


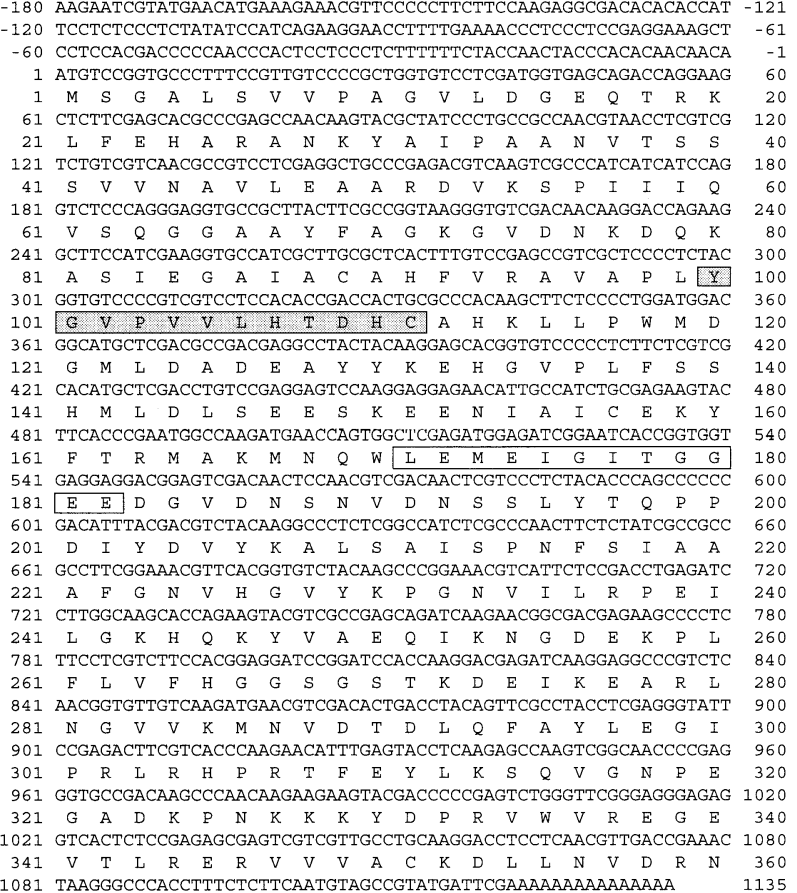

Fig. 1 Nucleotide and deduced amino acid sequences of the C. capitatum FBAl gene

The gray and white boxes indicate the aldolase class-II signature 1 and signature 2 , respectively.

to function as an FBA. In short, $C c F B A l$ encodes functional FBA in $C$. capitatum.

Moreover, we constructed a phylogenetic tree for FBAs of class II based on CcFbalp and other fungal FBAs. Fungal FBAs of class II compose two distinct subgroups, one primarily is basidiomycetes and the other is ascomycetes (Fig.2). This phylogenetic pattern agreed with that using $28 \mathrm{~S}$ rDNA (data not shown). This finding showed that CcFbalp evolved in basidiomycetes, and its evolution has been hardly affected by cold environments.

\section{Regulation of the CCFBA1 gene in various growth conditions.}

To obtain a regulatory insight into the expression of $F B A 1$ by several carbon sources in $C$. capitatum, we performed Northern analysis using a specific probe for the $C C F B A 1$.

At first, $C c F B A 1$ expression in $C$. capitatum grown on several carbon sources was monitored. As shown in Fig. 3, CCFBA1 was expressed during growth using glucose, glycerol, galacturonic acid and pectin, and generally expression levels were similar for each carbon source, although expression level on glucose was slightly higher than the others . Transcription of FBAl genes in $S$. cerevisiae and $K$.

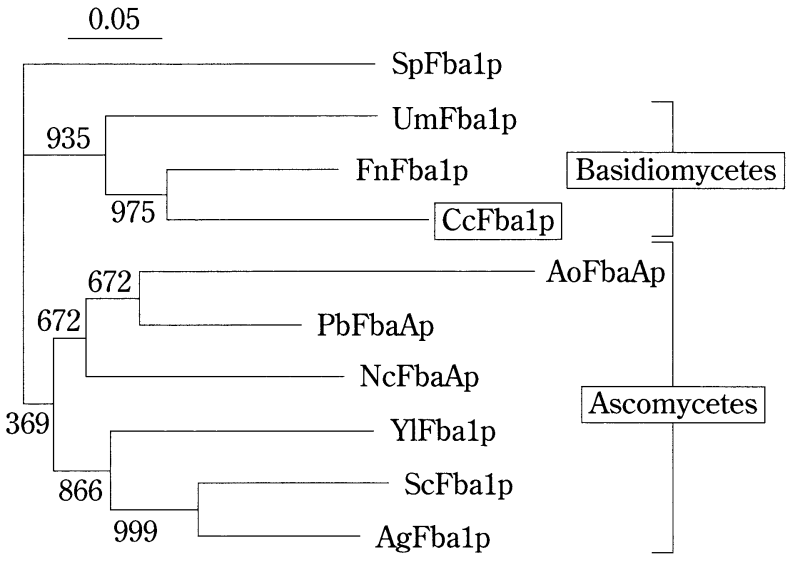

Fig. 2 Phylogenic relationships of class II FBAs from several fungal strains

The branching pattern was generated by the neighbor-joining method. The bar indicates 0.05 nucleotide substitutions per site. FBAs from; SpFbalp, Schizosaccharomyces pombe (AL 109731) ; UmFba 1 p, U. maydis (AX 710044) ; FnFba 1 p, F. neoformans var. neoformans (XM 568771) ; CcFba 1 p, C. capitatum ( $\mathrm{AB}$ 244669) ; AoFbaAp, Aspergillus oryzae (AB 032272) ; PbFbaAp, Paracoccidioides brasiliensis (AY 057387) ; NcFbaAp, N. crassa (L 42380) ; YlFbalp, Yarrowia lipolytica (CR 382131); ScFba 1 p, S. cerevisiae (X 15003) ; and AgFbalp, Ashbya gossypii (AE 016815).

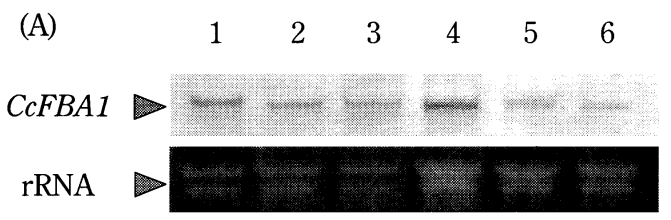

(B)

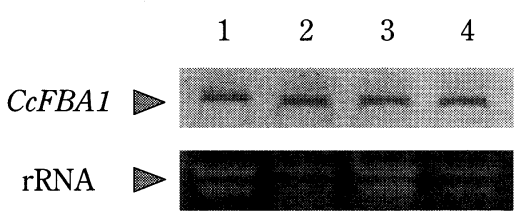

Fig. 3 Regulation of the $C c F B A l$ expression in $C$. capitatum

Total RNA $(20 \mu \mathrm{g})$ was loaded on each lane and probed with the CcFBAl.

(A) Effect of carbon sources. Growth conditions of each lane are : lane $1,1 \%(\mathrm{w} / \mathrm{w})$ galacturonic acid ; lane $2,1 \%(\mathrm{v} / \mathrm{w})$ glycerol ; lane $3,1 \%(\mathrm{w} / \mathrm{w})$ glucose (anaerobic) ; lane 4, $1 \%(\mathrm{w} / \mathrm{w})$ glucose (aerobic) ; lane $5,1 \%(\mathrm{w} / \mathrm{w})$ pectin (DE $10 \%)$; and lane $6,1 \%(\mathrm{w} / \mathrm{w})$ pectin (DE $94 \%)$.

(B) Effect of temperature. Growth conditions of each lane are : lane $1,5{ }^{\circ} \mathrm{C}$; lane $2,10^{\circ} \mathrm{C}$; lane $3,15^{\circ} \mathrm{C}$; and lane $4,20^{\circ} \mathrm{C}$ on pectin (DE $90 \%)$ medium.

lactis was not greatly influenced by the carbon source present in the media, e.g., glucose, glycerol and lactate $^{9), 10), 11)}$. It appears that CcFBAl is not regulated by catabolite repression. Oxygen did not influence the expression of CcFBAl (Fig.3), although the expression of $K l F B A 1$ is regulated by oxygen concentration . Expression of KlFBAl mRNA 
decreased during the shift from hypoxic to aerobic conditions and increased when these conditions were reversed ${ }^{11)}$.

ScFBAl has been reported to be a LOT (low temperature responsive) gene which is induced by cold stress ${ }^{1)}$. Since $C$. capitatum belongs to the psychrophilic yeast, we investigated whether expression of $C c F B A I$ was regulated by growth temperature or not. However, $C C F B A 1$ expressed at the same level at several growth temperatures (Fig. 3 B).

$C C F B A 1$ expressed strongly during lag phase, and its expression was reduced during stationary phase, although the gene is constitutively expressed (Fig. 4). These findings show CCFBAl is mainly expressed during cell division. Moreover, the gene is essential like the rRNA genes, but unlike rRNA gene expression patterns CCFBAl expression was reduced during the stationary phase. Therefore, expression of CcFBAI may be a marker for cell duplication, and the gene is potentially useful for the detection of microorganisms in putrid foods.

(A)

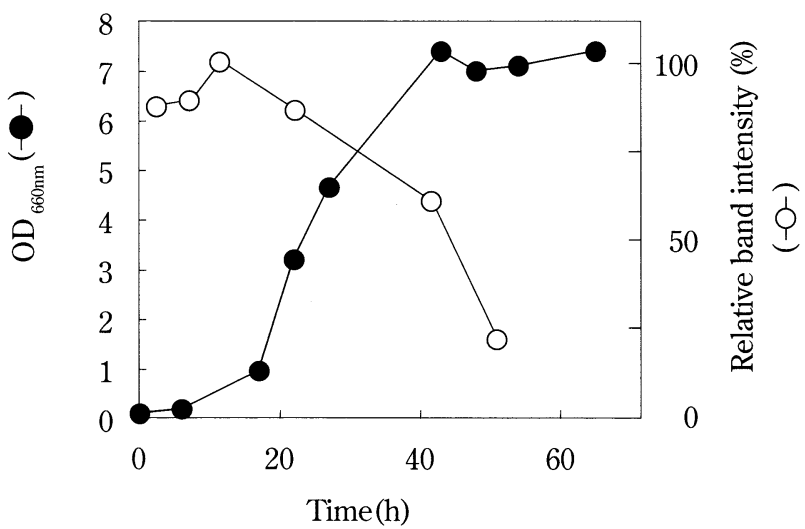

(B)

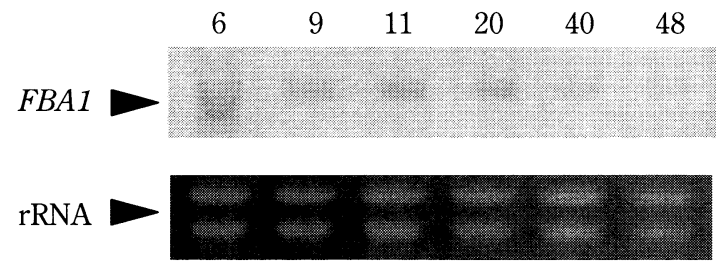

Fig. 4 Growth curve and expression ratio of the $C c F B A 1$ in C. capitatum

(A) Growth curve of $C$. capitatum on pectin $(\mathbf{)}$ ), and relative density of band corresponding with the $C_{C} F B A l$ in Northern analysis.

(B) Northern analysis.

\section{Conclusion}

In this study, we revealed the primary structure of FBA encoded by $C$. capitatum $F B A I$ and the regulation of its gene expression. The CcFbalp contains the aldolase class-II signature 1 and signature $2^{7)}$. CCFBAI is expressed constitutively and is not regulated by catabolite repression. These results show that $C c F B A 1$ encodes functional FBA in $C$. capitatum and CcFbalp has the ability to function as an FBA.

Expression of $C C F B A 1$ is not influenced by growth temperature. In $S$. cerevisiae, ScFBAl has been reported to be one of the LOT genes induced by cold stress ${ }^{1)}$. We think that this difference between the regulation of FBAls from $S$. cerevisiae and $C$. capitatum is related to the difference of growth features between these strains, i.e., S. cerevisiae is mesophilic, whereas $C$. capitatum is psychrophilic. It appears that $C$. capitatum has developed regulatory mechanisms of CcFBAl expression in order to adapt to cold habitats. Based on these facts, we propose that psychrophiles have evolved different gene regulatory systems besides cold-active enzymes to survive in low-temperature environments.

CcFBA1 is expressed constitutively. Expression of $C c F B A I$ is not influenced by lag and log phases and by presence of oxygen, although it was reduced during the stationary phase. We conclude that FBA could be a good target for the detection and quantification of psychrophiles in foodstuffs by the PCR method.

\section{References}

1 ) Zhang, L., Ohta, A., Horiuchi, H., Takagi, M. and IMAI, R.: Multiple mechanisms regulate expression of low temperature responsive (LOT) genes in Saccharomyces cerevisiae, Biochem. Biophys. Res. Commun., 283, 531 535 (2001)

2 ) Nakagawa, T., Nagaoka, T., Taniguchi, S., Miyaji, T. and TomizukA, N.: Isolation and characterization of psychrophilic yeasts producing cold-adapted pectinolytic enzymes, Lett. Appl . Microbiol., 38, 383 387 (2004)

3 ) Nakagawa, T., Yamada, K., Miyaji, T. and TomizUKA, N.: Cold-active pectinolytic activity of psychrophilic-basidiomycetous yeast Cystofilobasidium capitatum strain PPY-1, J. Biosci. Bioeng., 94, 175 177 (2002)

4 ) Sakai, Y., Nakagawa, T., Shimase, M. and Kato, N.: Regulation and physiological role of the DAS 1 
gene encoding dihydroxyacetone synthase in the methylotrophic yeast Candida boidinii, J. Bacteriol., 180, 5885 5890 (1998)

5 ) Saitou, N. and NeI, M.: The neighbor-joining method : a new method for reconstructing phylogenetic trees, Mol. Biol. Evol., 4, 406 425 (1987)

6 ) Felsenstein, J.: Confidence limits on phylogenies : an approach using the bootstrap, Evolution., 39, 783 〜91 (1985)

7 ) Berry, A. and Marshall, K. E.: Identification of zinc-binding ligands in the class II fructose-1, 6bisphosphate aldolase of Escherichia coli, FEBS Lett., 318, 11 16 (1993)

8 ) Marsh, J. J. and Lebherz, H. G. : Fructosebisphosphate aldolases: an evolutionary history, Trends. Biochem. Sci., 17, 110 113 (1992)

9 ) Compagno, C., Ranzi, B. M. and Martegani, E. : The promoter of Saccharomyces cerevisiae FBAI gene contains a single positive upstream regulatory element, FEBS Lett., 293, 97 100 (1991)

10) Maitra, P. K. and Lobo, Z.: A kinetic study of glycolytic enzyme synthesis in yeast, J. Biol. Chem., 246, 475 488 (1971)

11) Prado, S. M., Cerdan, M. E. and Gonzalez Siso, M. I.: Isolation and transcriptional regulation of the Kluyveromyces lactis FBA1 (fructose-1, 6bisphosphate aldolase) gene, Can. J. Microbiol., 50, $645 \sim 652$ (2004)

\section{低温性酵母 Cystofilobasidium capitatum 由来}

アルドラーゼの一次構造とその発現制御

藤村朱喜 ${ }^{* 1} \cdot$ 内野昌孝 ${ }^{* 2} \cdot$ 伊藤尚志 ${ }^{* 1}$

妙田貴生 ${ }^{* 1} \cdot$ 長岡俊紀 ${ }^{* 1} \cdot$ 宮地竜郎*1

中川智行 ${ }^{* 1} \cdot$ 高野克己 ${ }^{* 2} \cdot$ 冨塚 登*1

* 1 東京農業大学生物産業学部食品科学科

（邓099-2493 北海道網走市八坂196）

* 2 東京農業大学応用生物科学部生物応用化学科

（テ156-8502 東京都世田谷区桜丘 1-1－1）

本研究では, 低温性ペクチン資化性酵母 Cystofilobasidium capitatum 由来アルドラーゼの一次構造 とその発現制御について解析を行った。C. capitatumの アルドラーゼをコードする遺伝子FBAIは360アミノ酸残 基をコードしうるORFからなり，その遺伝子産物CcFba $1 \mathrm{p}$ はアルドラーゼに特有の保存配列を保持しており， 推定分子量は39,626Daであった。一方，FBA1はグルコ ースにより若干の高発現がみられるものの，炭素源や温 度，酸素濃度にはほとんど影響されなかった。さらに， $F B A 1$ は定常期において発現の低下がみられるものの, 誘導期および対数増殖期においては安定した発現が観察 された。これらの結果から，FBAIはC. capitatumにおい て構成的に発現されるハウスキーピング遺伝子の一つで あり，本遺伝子が食品中におけるこれら低温性䣲母の検 出の指標に用いることができる可能性を示した。

(平成18年 9 月 11 日受付, 平成18年12月 6 日受理) 